
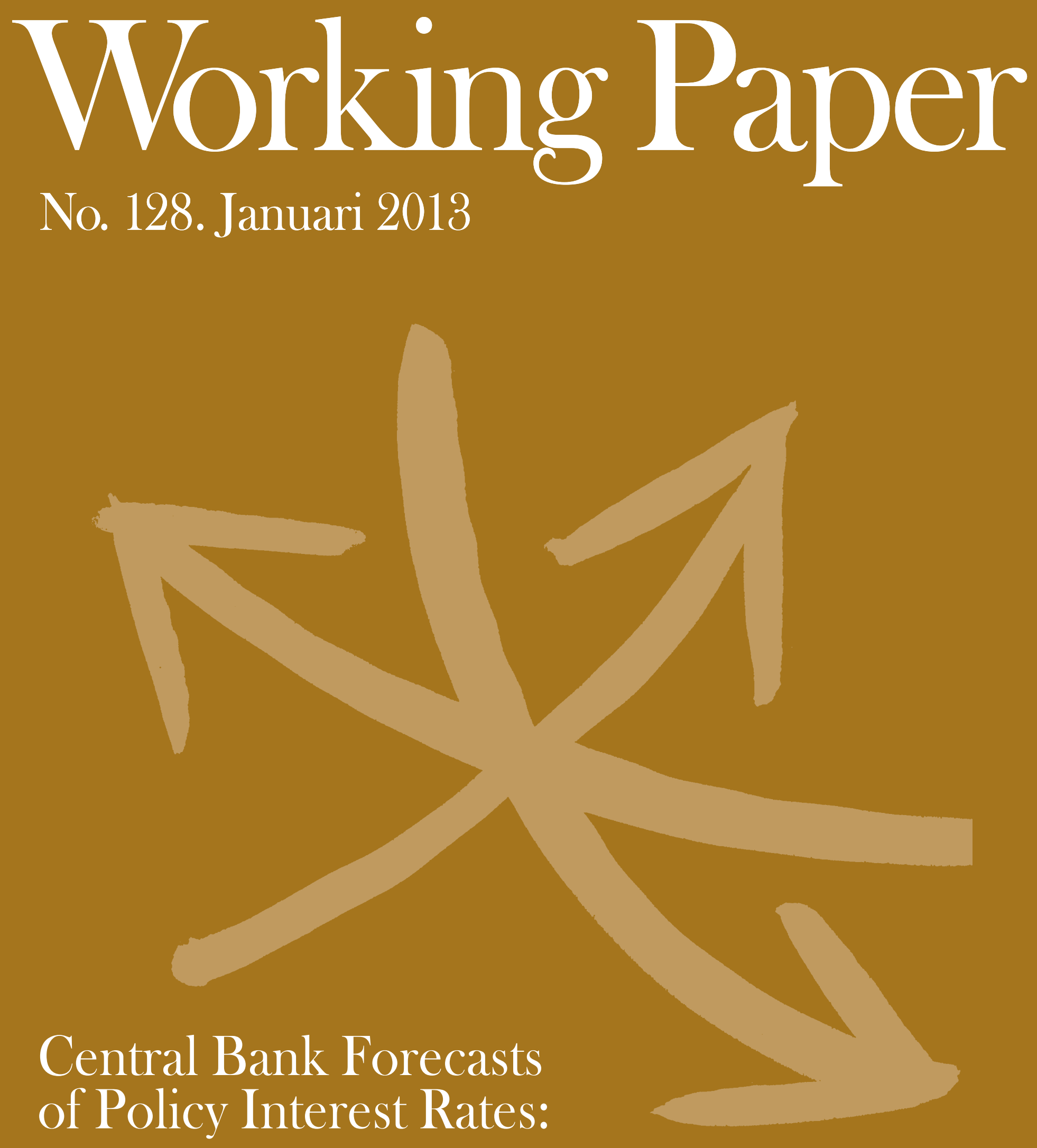

An Evaluation of the First Years

By Meredith Beechey

and Pär Österholm

National Institute of Economic Research

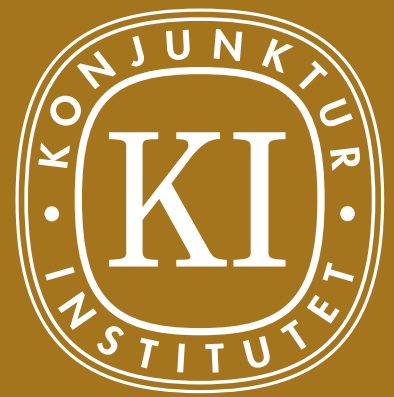





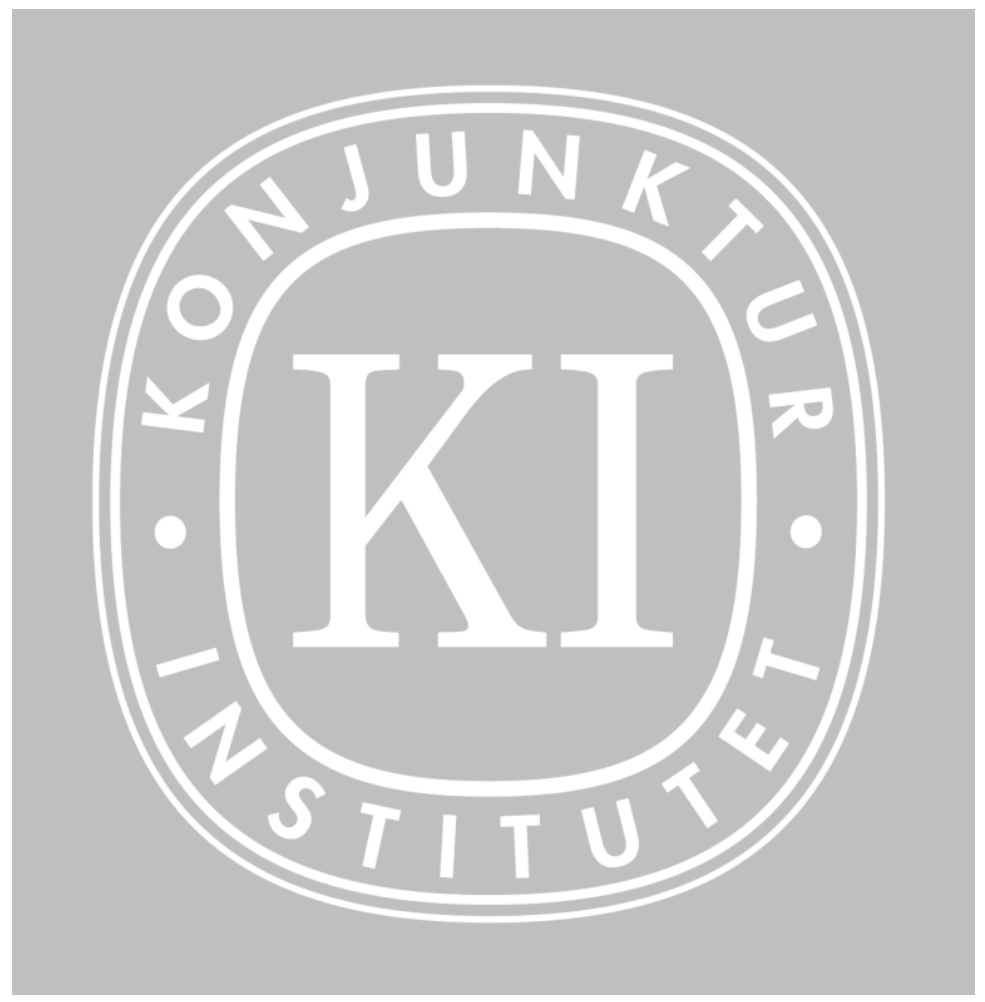

\title{
Central Bank Forecasts of Policy Interest Rates: An Evaluation of the First Years*
}

\author{
Meredith Beechey ${ }^{\#}$ \\ Pär Österholm*
}

\begin{abstract}
* We are grateful to Jesper Hansson, Göran Hjelm and seminar participants at the National Institute of Economic Research for valuable comments. The views expressed in this paper are solely the responsibility of the authors and should not be interpreted as reflecting the views of the Executive Board of Sveriges Riksbank.
\end{abstract}

\# Sveriges Riksbank, 10337 Stockholm, Sweden

e-mail: meredith.beechey@riksbank.se Phone: +46 87870449

* National Institute of Economic Research, Box 3116, 10362 Stockholm, Sweden

e-mail: par.osterholm@konj.se Phone: +46 84535948

WORKING PAPER NR 128, JANUARY 2013 
NIER prepares analyses and forecasts of the Swedish and international economy and conducts related research. NIER is a government agency accountable to the Ministry of Finance and is financed largely by Swedish government funds. Like other government agencies, NIER has an independent status and is responsible for the assessments that it publishes.

The Working Paper series consists of publications of research reports and other detailed analyses. The reports may concern macroeconomic issues related to the forecasts of the institute, research in environmental economics, or problems of economic and statistical methods. Some of these reports are published in their final form in this series, whereas others are previews of articles that are subsequently published in international scholarly journals under the heading of Reprints. Reports in both of these series can be ordered free of charge. Most publications can also be downloaded directly from the NIER home page. 


\begin{abstract}
In recent years the central banks of Norway and Sweden have published their endogenous policy interest-rate forecasts. In this paper, we evaluate those forecasts alongside policy-rate expectations inferred from market pricing. We find that for both economies there are only small differences in relative forecasting precision between the central bank and market-implied measures. However, both types of forecast fail tests for unbiasedness and efficiency at longer horizons.
\end{abstract}

JEL Classification: E52

Keywords: Monetary policy, Market expectations, Norges Bank, Sveriges Riksbank 


\section{Summary in Swedish}

På senare år har centralbankerna i Norge och Sverige publicerat sina endogena styrränteprognoser. I denna studie utvärderar vi dessa prognoser tillsammans med styrränteförväntningar beräknade utifrån marknadsprissättningen. Vi finner att det är små skillnader $\mathrm{i}$ prognosprecision mellan centralbanken och marknadsbaserade mått i såväl Norge som Sverige. Resultaten visar även att såväl centralbankernas prognoser som styrränteförväntningar beräknade utifrån marknadsprissättningen är behäftade med frånvaro av förväntningsriktighet och ineffektivitet på längre horisonter. 


\section{Contents}

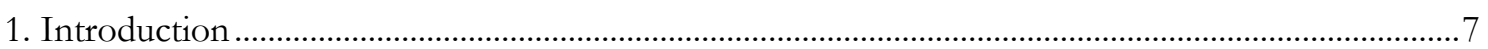

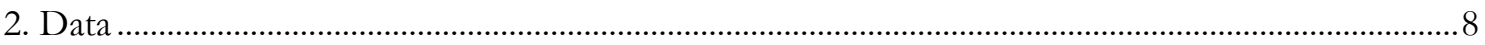

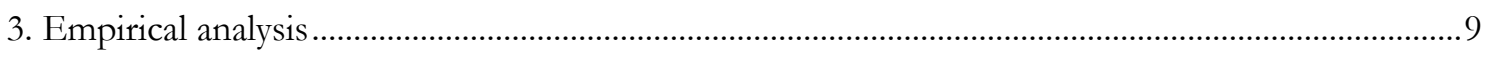

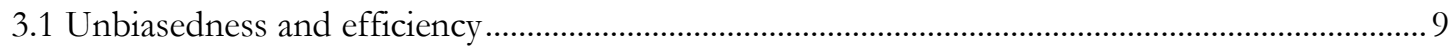

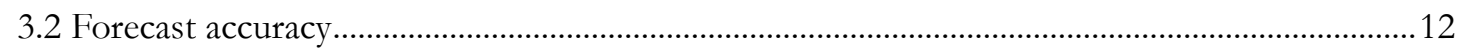

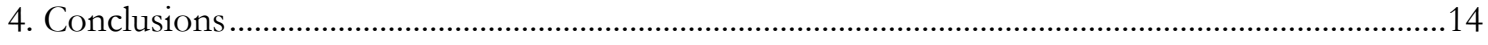

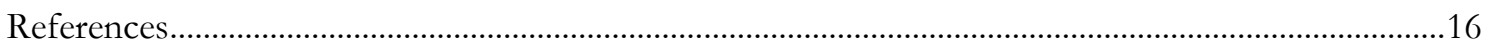

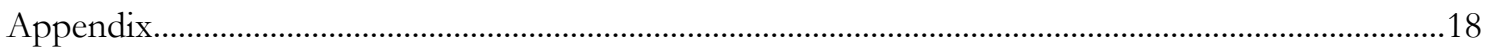





\section{Introduction}

Central bank transparency has increased dramatically over the last two decades as inflation targeting has become a standard framework for monetary policy. The benefits of an open and transparent monetary-policy process are widely agreed upon by policymakers and academics and have led to explicit numerical targets for inflation, publication of minutes from policy-decision meetings and comprehensive monetary policy reports containing forecasts of a large number of variables and detailed descriptions of the analysis behind them.

One of the more recent aspects of the increasing transparency is central banks publishing their own forecasts of the policy interest rate. This is by no means uncontroversial and a lively discussion has arisen about the associated costs and benefits and ultimately the limits to transparency; see, for example, Morris and Shin (2002), Mishkin (2004), Svensson (2006), Blinder et al. (2008), Rudebusch (2008), van der Cruijsen et al. (2010) and Ehrmann et al. (2012). Proponents argue that publishing the policy-rate path helps economic agents better understand monetary policy and lends the central bank more influence over longer-term interest rates, thereby improving the central bank's ability to achieve its macroeconomic objectives. Opponents argue that the policy rate path is too uncertain to be worth communicating and point to a risk that the path might be misinterpreted as commitment. While there is no consensus, some academic research suggests that it might be beneficial to publish the path. For example, Rudebusch and Williams (2008) show - using a small theoretical model with private sector imperfect information - that it generally generates better aligned expectations and helps the central bank to achieve its goals.

With the benefits uncertain, few central banks have so far chosen to publish a forecast for the policy rates. There is accordingly yet little data to analyse regarding questions relating to this issue. However, Norges Bank and Sveriges Riksbank took the step early; the former started publishing its own policy rate forecast in October 2005 and the latter followed in February 2007.1

The purpose of this paper is to evaluate the forecasting properties of policy interest-rate forecasts of the central banks of Norway and Sweden, alongside policy-rate expectations inferred from financial market pricing. We evaluate unbiasedness, efficiency and precision using a standard framework. This analysis provides relevant information on a number of issues. Central banks' forecasts and market expectations diverge at times, creating a tension between outlooks. ${ }^{2}$ The divergence can owe to measurement problems when extracting market expectations from interest rates on finan-

\footnotetext{
${ }^{1}$ It should be noted that the Reserve Bank of New Zealand was the true pioneer when it comes to endogenous interestrate forecasts but it provides a forecast of the 90 -day bank bill rate, not its own policy rate (the OCR rate).

${ }^{2}$ For example, Figure A1 in the appendix shows the Riksbank's repo rate forecasts and market expectations in Sweden in October 2010 as presented in the Monetary Policy Report October 2010.
} 
cial-market instruments but may also reflect different outlooks about the economy and policy rate. That is, at times the central bank's policy-rate path may not be fully credible. When the forecast paths do diverge, one can ask which will prove to be the better forecast and on which path economic agents would do best to rely. At any given time, the answer to those questions will depend on a range of factors but this paper aims to present some facts from the realised sample so far. Our results show that neither the central banks' forecasts nor market expectations pass simple tests for unbiasedness and efficiency but that there are generally very small differences in forecasting precision between central banks and market expectations.

The rest of this paper is organised as follows. In Section 2, we describe the data used. Section 3 presents the empirical analysis and, finally, Section 4 concludes.

\section{Data}

Norges Bank's forecasts of the sight deposit rate are those published in the Inflation Report or Monetary Policy Report from October 2005 to June 2012.3 Similarly, Sveriges Riksbank's forecasts of the repo rate are those published in the Monetary Policy Report and Monetary Policy Update from February 2007 to July 2012. Data on market expectations inferred from financial market data were provided by Norges Bank and Sveriges Riksbank.

In our empirical analysis, we focus on forecast performance at three different horizons: one quarter, one year and two years. Figures A2 to A4 in the appendix show the forecast errors - defined as $e_{t+h \mid t}=i_{t+h}-i_{t+h \mid t}$, where $i_{t+h}$ is the policy rate at time $t+h$ and $i_{t+h \mid t}$ is the forecast made at time $t-$ at the different horizons in Norway. Figures A5 to A7 in the appendix show the corresponding forecast errors in Sweden.

Figure 1 shows the policy interest rates in Norway and Sweden from January 2005 to September 2012. As can be seen, the sample employed for our evaluation includes the tightening phase which ended in late 2008, the dramatic cuts of late 2008 and early 2009 and the period of very low rates which ensued.

\footnotetext{
${ }^{3}$ Norges Bank changed the name of their main report from Inflation Report to Monetary Policy Report in 2007.
} 
Figure 1. Policy interest rates in Norway and Sweden.

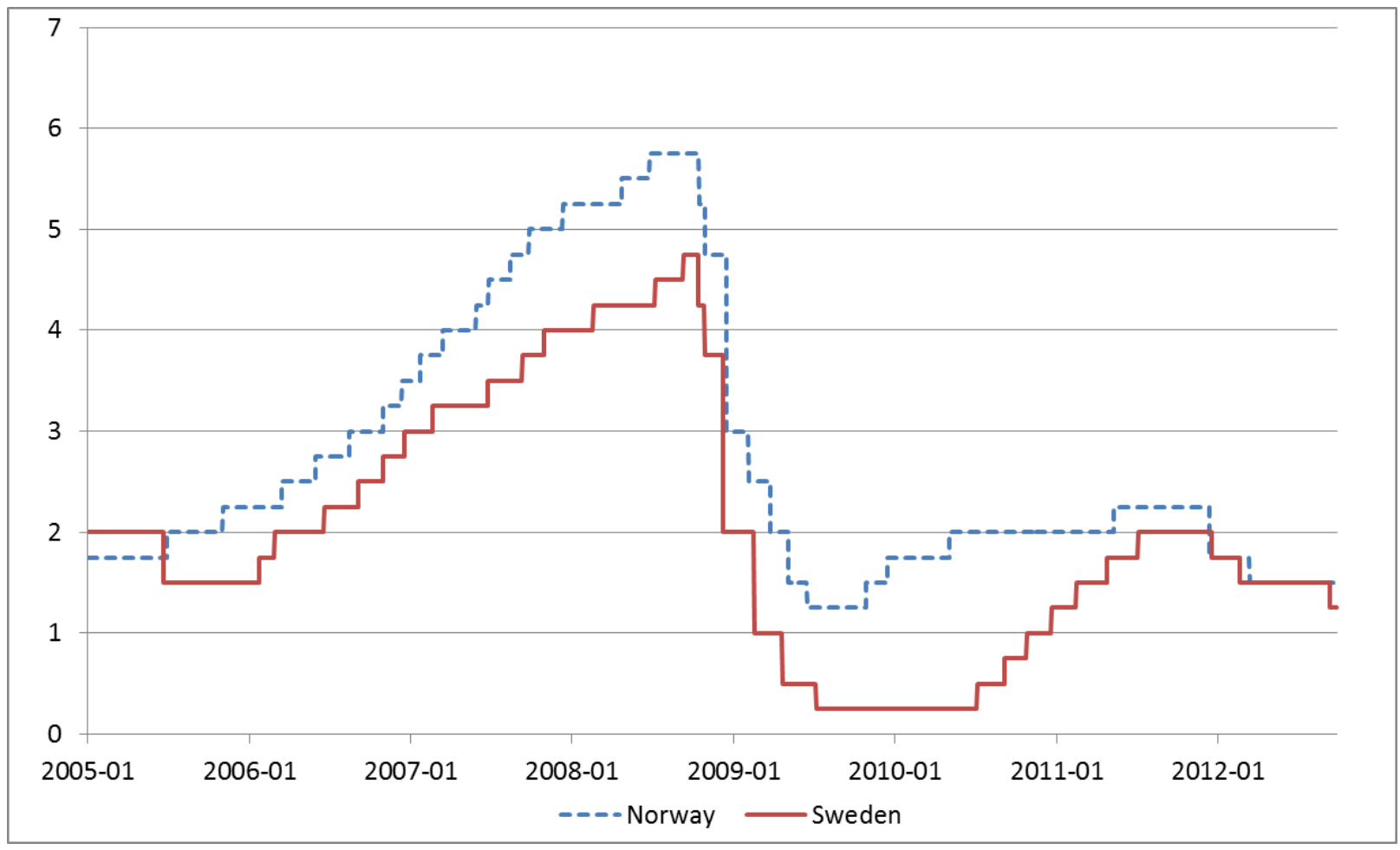

\section{Empirical analysis}

Our empirical analysis is divided into two parts. First, we test for unbiasedness and efficiency. Second, we assess the forecast precision of the different forecasts and expectations. The framework employed is standard in the forecast evaluation literature; see, for example, Mehra (2002), Mankiw et al. (2003), Baghestani (2008) and Jonsson and Österholm (2011).

\subsection{Unbiasedness and efficiency}

We first test for unbiasedness, that is, whether the forecast errors have a zero mean. Results are shown in Table 1. For the available samples, all forecasts at all horizons have on average overpredicted the policy-rate outcome in both countries. The extent of the over-prediction is larger in Sweden at one- and two-year horizons and owes in part to the very low interest rates that prevailed during 2009 and 2010. Having quantified the extent of the over-prediction, we ask whether it constitutes a significant bias. This is tested by running the regression

$i_{t+h}-i_{t+h \mid t}=\lambda+\omega_{t}$, 
where $i_{t+h}$ and $i_{t+h \mid t}$ are defined as above and $\omega_{t}$ is an error term. The null hypothesis $H_{0}: \lambda=0$ is then tested using a standard $t$-test. ${ }^{4}$ As can be seen from Table 1 , the null hypothesis can be rejected at the two-year horizon for both Norges Bank's forecasts (at the ten percent level) and the market expectations (at the five percent level). In Sweden, both the Riksbank's forecasts and market pricing are found to have a significant bias (at conventional levels) at the two longest forecast horizons. Biased forecasts constitute a violation of rational expectations when the forecaster has a symmetric quadratic loss function (which is a common assumption in the literature on forecast evaluations) but not necessarily so if the loss function is asymmetric. ${ }^{5}$ In reality, the forecasters' loss function is not known, clouding an assessment of whether forecasts have been rational over this sample. One should also keep in mind that the sample is short and contains much variation in the policy cycle. For example, forecasts and expectations at the two-year horizon in Sweden from 2007 and the first half of 2008 were generated by agents who were blissfully unaware of the upcoming financial crisis and who overestimated the repo rate substantially.

${ }^{4}$ Newey-West standard errors are used to address the serial correlation in the residuals.

${ }^{5}$ See, for example, Elliott et al. (2008). 
Table 1. RMSEs and results from tests of bias and efficiency.

\begin{tabular}{|c|c|c|c|c|c|c|}
\hline & \multicolumn{3}{|c|}{ Norway } & \multicolumn{3}{|c|}{ Sweden } \\
\hline & Mean error & Efficiency & RMSE & Mean error & Efficiency & RMSE \\
\hline \multicolumn{7}{|l|}{1 quarter } \\
\hline Central bank & $\begin{array}{l}-0.11 \\
(0.09)\end{array}$ & $\begin{array}{l}-0.10 \\
(0.08)\end{array}$ & 0.43 & $\begin{array}{l}-0.14 \\
(0.10)\end{array}$ & $\begin{array}{l}-0.13 \\
(0.08)\end{array}$ & 0.43 \\
\hline Market pricing & $\begin{array}{l}-0.13 \\
(0.08)\end{array}$ & $\begin{array}{l}-0.06 \\
(0.05)\end{array}$ & 0.36 & $\begin{array}{l}-0.08 \\
(0.11)\end{array}$ & $\begin{array}{l}-0.14 \\
(0.09)\end{array}$ & 0.44 \\
\hline Naive & $\begin{array}{l}-0.13 \\
(0.23)\end{array}$ & - & 0.79 & $\begin{array}{l}-0.14 \\
(0.22)\end{array}$ & - & 0.76 \\
\hline \multicolumn{7}{|l|}{1 year } \\
\hline Central bank & $\begin{array}{l}-0.65 \\
(0.43)\end{array}$ & $\begin{array}{l}-0.55^{b} \\
(0.23)\end{array}$ & 1.46 & $\begin{array}{l}-0.94^{c} \\
(0.47)\end{array}$ & $\begin{array}{l}-0.72^{a} \\
(0.19)\end{array}$ & 1.74 \\
\hline Market pricing & $\begin{array}{l}-0.63 \\
(0.39)\end{array}$ & $\begin{array}{l}-0.44^{b} \\
(0.23)\end{array}$ & 1.36 & $\begin{array}{l}-0.85^{c} \\
(0.44)\end{array}$ & $\begin{array}{l}-0.66^{a} \\
(0.19)\end{array}$ & 1.62 \\
\hline Naive & $\begin{array}{l}-0.27 \\
(0.65)\end{array}$ & - & 1.81 & $\begin{array}{l}-0.52 \\
(0.61)\end{array}$ & - & 1.92 \\
\hline \multicolumn{7}{|l|}{2 years } \\
\hline Central bank & $\begin{array}{l}-1.37^{c} \\
(0.65)\end{array}$ & $\begin{array}{l}-0.69^{b} \\
(0.31)\end{array}$ & 2.18 & $\begin{array}{l}-2.01^{a} \\
(0.63)\end{array}$ & $\begin{array}{l}-0.78^{a} \\
(0.16)\end{array}$ & 2.60 \\
\hline Market pricing & $\begin{array}{l}-1.41^{b} \\
(0.65)\end{array}$ & $\begin{array}{l}-0.68^{c} \\
(0.33)\end{array}$ & 2.21 & $\begin{array}{l}-1.90^{a} \\
(0.62)\end{array}$ & $\begin{array}{l}-0.83^{a} \\
(0.13)\end{array}$ & 2.53 \\
\hline Naive & $\begin{array}{l}-0.59 \\
(0.94)\end{array}$ & - & 2.41 & $\begin{array}{l}-1.09 \\
(0.89)\end{array}$ & - & 2.58 \\
\hline
\end{tabular}

Note: "Mean error" gives $\hat{\lambda}$ from equation (1). "Efficiency" gives $\hat{\beta}$ from equation (2). ${ }^{\mathrm{a}}$, ${ }^{\mathrm{b}}$ and ${ }^{\mathrm{c}}$ indicate significance at the one, five and ten percent level respectively. Newey-West standard errors in parentheses (). Regressions have 22, 19 and 16 observations at the one-quarter, one-year and two-year horizons in Norway. Regressions have 31, 26 and 20 observations at the one-quarter, one-year and two-year horizons in Sweden.

Next, we test for efficient use of macroeconomic data when forming expectations. A straightforward test of efficient use of data tests whether current information about the policy rate is systematically related to the forecast error and is based on the regression

$i_{t+h}-i_{t+h \mid t}=\alpha+\beta i_{t}+v_{t}$

where $i_{t+h}$ and $i_{t+h \mid t}$ are defined as above and $v_{t}$ is an error term. As $i_{t}$ was in the information set at time $t$, efficient use of data requires that it cannot explain variation in the forecast errors. The null hypothesis $H_{0}: \beta=0$ is tested using a standard $t$-test (with Newey-West standard errors). Results 
are given in Table $1 .^{6}$ At the one-quarter horizon, there are no signs of inefficient use of data in either country. However, looking at the results for the two longest horizons, we see that both the forecasts of the central banks as well as market expectations are judged inefficient (at the five or ten percent level in Norway and at the one percent level in Sweden). While bias is not necessarily a sign of lack of rationality, inefficient use of data is incompatible with strictly rational expectations. However, both central banks and private agents operate with incomplete information about the economy and its dynamics, making fully rational expectations perhaps an excessively demanding benchmark.

\subsection{Forecast accuracy}

As the last step in our assessment of the policy-rate expectations, we compare the forecasting precision of the central banks' forecasts to the expectations inferred from market pricing. Results are once again given in Table 1.

Turning to Norway, forecast errors generally are small at the one-quarter horizon. The root mean square errors (RMSEs) for Norges Bank and market expectations are 0.43 and 0.36 respectively. Reflecting the difficulties of forecasting, absolute forecast errors are on average larger the longer the forecast horizon. At the one-year horizon, Norges Bank's RMSE is 1.46 and market expectations' 1.36; at the two-year horizon, the corresponding numbers are 2.18 and 2.21. As can be seen from Figures A2, A3 and A4, both market-inferred expectations and Norges Bank over-predicted the future policy rate substantially before the dramatic cut of December 2008. This is particularly evident for one- and two-year ahead forecasts in which the forecast miss affects forecast errors for several subsequent periods. ${ }^{7}$ The market-inferred expectations exhibit slightly higher forecast precision than Norges Bank's forecasts at the two shorter horizons but the difference is small at all horizons. Naïve forecasts exhibit the largest RMSEs at all horizons.

To test if there are any significant differences in forecasting performance between Norges Bank and the alternatives we conduct a modified Diebold-Mariano test under the assumption of a quadratic loss function. ${ }^{8}$ This is based on the regression

$\left(e_{t+h \mid t}^{C B}\right)^{2}-\left(e_{t+h \mid t}^{a l t}\right)^{2}=\delta+\chi_{t}$,

\footnotetext{
${ }^{6}$ We do not test for efficient use of data when it comes to the naïve forecast. It is after all a simple benchmark and should of course be treated as such.

${ }^{7}$ Recall that by definition the forecast error of an $h$-step ahead forecast is serially correlated. Even an efficient forecast for horizon $h$ has an $\mathrm{MA}(h-1)$ structure.

${ }^{8}$ We use the modified test of Harvey et al. (1997) rather than the orignial one suggested by Diebold and Mariano (1995) since our samples are fairly small.
} 
where $e_{t+h \mid t}^{C B}$ are the forecast errors of the central bank and $e_{t h \mid t}^{a l t}$ are the forecast errors of the alternative method we are comparing it to, that is, either market pricing or the naïve forecast; $\chi_{t}$ is an error term. The null hypothesis is that the forecast accuracy of the central bank is equal to that of the alternative and is tested by comparing a transformation of the $t$-statistic on $\hat{\delta}$ to the relevant critical value from the $t$-distribution. Results are shown in Table 2 . The null hypothesis cannot be rejected in a single case and we hence conclude that there is no support for a difference in forecast accuracy.

Table 2. Results from modified Diebold-Mariano test.

\begin{tabular}{lcc} 
& Norway & Sweden \\
\hline $\mathbf{1}$ quarter & & \\
Market pricing & 0.90 & -1.58 \\
Naive & -1.39 & -1.44 \\
\hline $\mathbf{1}$ year & & \\
Market pricing & 1.29 & $1.72^{\mathrm{c}}$ \\
Naive & -1.03 & -0.83 \\
\hline years & & \\
Market pricing & -0.13 & 0.64 \\
Naive & -0.33 & 0.08 \\
\hline
\end{tabular}

Note: Entries in the table are the test statistic from the modified Diebold and Mariano test of Harvey et al. (1997). ${ }^{a}{ }^{b}$ and ${ }^{c}$ indicate significance at the one, five and ten percent level respectively. Regressions have 22, 19 and 16 observations at the one-quarter, one-year and two-year horizons in Norway. Regressions have 31, 26 and 20 observations at the one-quarter, one-year and two-year horizons in Sweden.

The results for Sweden show that the Riksbank has the lowest RMSE at the one-quarter horizon, albeit only marginally less than that of market-inferred expectations. At the one- and two-year horizons, the Riksbank's forecasting performance is slightly poorer than that of market-inferred expectations; at the one-year horizon, the modified Diebold-Mariano test suggests that this difference is statistically significant at the ten percent level. At the two-year horizon, the Riksbank also performs worse than a naïve forecast but the differences between the different measures at this horizon are quantitatively small and in no case statistically significant.

Overall, there is little support for a qualitative difference between central banks' forecasts and market-implied expectations of the policy rate. The forecasts follow similar patterns over time and it is evident from Figures A2 to A7 that neither the central banks nor markets foresaw the abrupt cut in policy rates in the immediate wake of the financial crisis. 
Both Norges Bank and the Riksbank do reasonably well relative to a naïve forecast. Norges Bank outperforms it at all horizons, as does the Riksbank at the three-month and one-year horizons. That is, central banks add information above and beyond a naïve forecast at reasonably long horizons, calling into question Goodhart and Lim's (2011) suggestion that central banks should adopt a more mechanical approach - such as a no-change or implied forward market rate assumption - at horizons beyond two quarters. ${ }^{9}$

Goodhart and Lim's (2011) recommendation can also be questioned on other grounds. Both a constant policy interest rate over the forecast horizon and implied forward market rates have been used and later abandoned by several central banks (including Norges Bank and Sveriges Riksbank); drawbacks included difficulties in generating and interpreting the forecasts and indeterminacy in forecasting scenarios. ${ }^{10}$ There is also intuitive theoretical appeal in the idea that communicating the outlook aids private agents' decision making about consumption and investment - thereby improving the implementation of monetary policy. Publishing endogenous interest-rate forecasts is also in line with the conclusions of Faust and Leeper (2005) and Faust and Wright (2008) that unconditional forecasts of the policy interest rate (and goal variables) provide a more effective means of communication than conditional forecasts.

\section{Conclusions}

The results in this paper reveal only modest differences in forecast precision between central banks' policy-rate projections and market-implied rate expectations. From a policy point of view, this is interesting for a number of reasons. First, it is probably comforting for proponents of endogenous interest-rate path publications that the central bank's forecast precision is roughly on par with the market's and generally superior to a naïve forecast. From that benchmark, concerns that publication of central-bank projections may prompt a deterioration in other agents' forecasts seems unwarranted. ${ }^{11}$ Second, the relatively even forecast performance - combined with the fact that the central banks do fairly well compared to a naïve forecast - does not lend support for Goodhart and Lim's (2011) recommendation that central banks should abandon their own forecasts in favour of marketimplied expectations or no-change forecasts. Third, when divergences do arise between the central bank and the market-implied forecasts, the results in this paper do not give strong priors about how the divergence will be resolved. After all, market-implied expectations have, over these samples, been as fair a guide to future developments as central-bank forecasts.

\footnotetext{
9 Specifically, Goodhart and Lim (2011) evalutate short-term interest rate forecasts in New Zealand and the United Kingdom where the former are the forecasts of the Reserve Bank of New Zealand and the latter have been derived from money market yield curves. They conclude (p. 135) that the forecasts "... have been excellent for the immediate forthcoming quarter, reasonable for the next quarter, and useless thereafter".

10 See, for example, Ólafsson (2007) for a discussion.

11 Dale et al. (2011) suggest that a central bank which publishes forecasts of poor quality risks causing the private sector's forecast precision to deteriorate.
} 
However, both central-bank projections and expectations inferred from market pricing fail tests for bias and inefficiency at longer forecast horizons. This may reflect difficulties in forecasting during a turbulent period or more fundamentally, incomplete knowledge of the structure and dynamics of the economy. The results nevertheless indicate that forecasts do not live up to the demanding standards of fully rational expectations. 


\section{References}

Baghestani, H. (2008), "Federal Reserve versus Private Information: Who Is the Best Unemployment Rate Predictor?", Journal of Policy Modeling 30, 101-110.

Blinder, A., Ehrmann, M., Fratzscher, M., de Haan, J. and Jansen, D.-J. (2008), "Central Bank Communication and Monetary Policy: A Survey of the Evidence", Journal of Economic Literature 46, 910-945.

Dale, S., Orphanides, A. and Österholm, P. (2011), "Imperfect Central Bank Communication: Information versus Distraction", International Journal of Central Banking 7, 3-39.

Diebold F. X. and Mariano R. S. (1995), "Comparing Predictive Accuracy", Journal of Business and Economic Statistics 13, 253-263.

Ehrmann, M., Eijffinger, S. C. W. and Fratzscher, M. (2012), “The Role of Central Bank Forecasts for Guiding Private Sector Forecasts", Scandinavian Journal of Economics 114, 1018-1052.

Elliott, G., Komunjer, I. and Timmermann, A. (2008), "Biases in Macroeconomic Forecasts: Irrationality or Asymmetric Loss?”, Journal of the European Economic Association 6, 122-157.

Faust, J. and Leeper, E. M. (2005), "Forecasts and Inflation Reports: An Evaluation”, Paper presented at Sveriges Riksbank's conference Inflation targeting: implementation, communication and effectiveness, June 2005.

Faust, J. and Wright, J. H. (2008), "Efficient Forecast Tests for Conditional Policy Forecasts", Journal of Econometrics 146, 293-303.

Goodhart, C. A. E. and Lim, W. B. (2011), "Interest Rate Forecasts: A Pathology”, International Journal of Central Banking 7, 135-171.

Harvey, D., Leybourne, S. and Newbold, P. (1997), "Testing the Equality of Prediction Mean Squared Errors”, International Journal of Forecasting 13, 281-291.

Jonsson, T. and Österholm, P. (2011), “The Forecasting Properties of Survey-Based Wage-Growth Expectations”, Economics Letters 113, 276-281.

Mankiw, N. G., Reis, R., Wolfers, J. (2003), “Disagreements about Inflation Expectations”, NBER Macroeconomics Annual 18, 209-248.

Mehra, Y. P. (2002), "Survey Measures of Expected Inflation: Revisiting the Issues of Predictive Content and Rationality", Federal Reserve Bank of Richmond Quarterly Review 88, 17-36.

Mishkin, F. S. (2004), “Can Central Bank Transparency Go Too Far?”, In: Kent, C. and Guttman, S. (eds), The Future of Inflation Targeting, Reserve Bank of Australia, Sydney.

Morris, S. and Shin, H. S. (2002), "Social Value of Public Information", American Economic Review 92, 1521-1534.

Ólafsson, T. T. (2007), "Publications of Its Own Policy Rate Path Boosts the Effectiveness of Central Bank Monetary Policy", Central Bank of Iceland Monetary Bulletin 2007/1, 71-86. 
Rudebusch, G. D. (2008), "Publishing Central Bank Interest Rate Forecasts”, Federal Reserve Bank of San Francisco Economic Letter 2008-02.

Rudebusch, G. D. and Williams, J. C. (2008), "Revealing the Secrets of the Temple: The Value of Publishing Central Bank Interest Rate Projections", In: Campbell, J. Y. (ed), Asset Prices and Monetary Policy, University of Chicago Press, Chicago.

Svensson, L. E. O. (2006), "Social Value of Public Information: Morris and Shin (2002) Is Actually Pro-Transparency, Not Con”, American Economic Review 96, 448-452.

Sveriges Riksbank (2010), Monetary Policy Report October 2010.

van der Cruijsen, C. A. B., Eijffinger, S. C. W. and Hoogduin, L. H. (2010), "Optimal Central Bank Transparency", Journal of International Money and Finance 29, 1482-1507. 


\section{Appendix}

Figure A1. Repo rate and forecasts/expectations in Sweden.

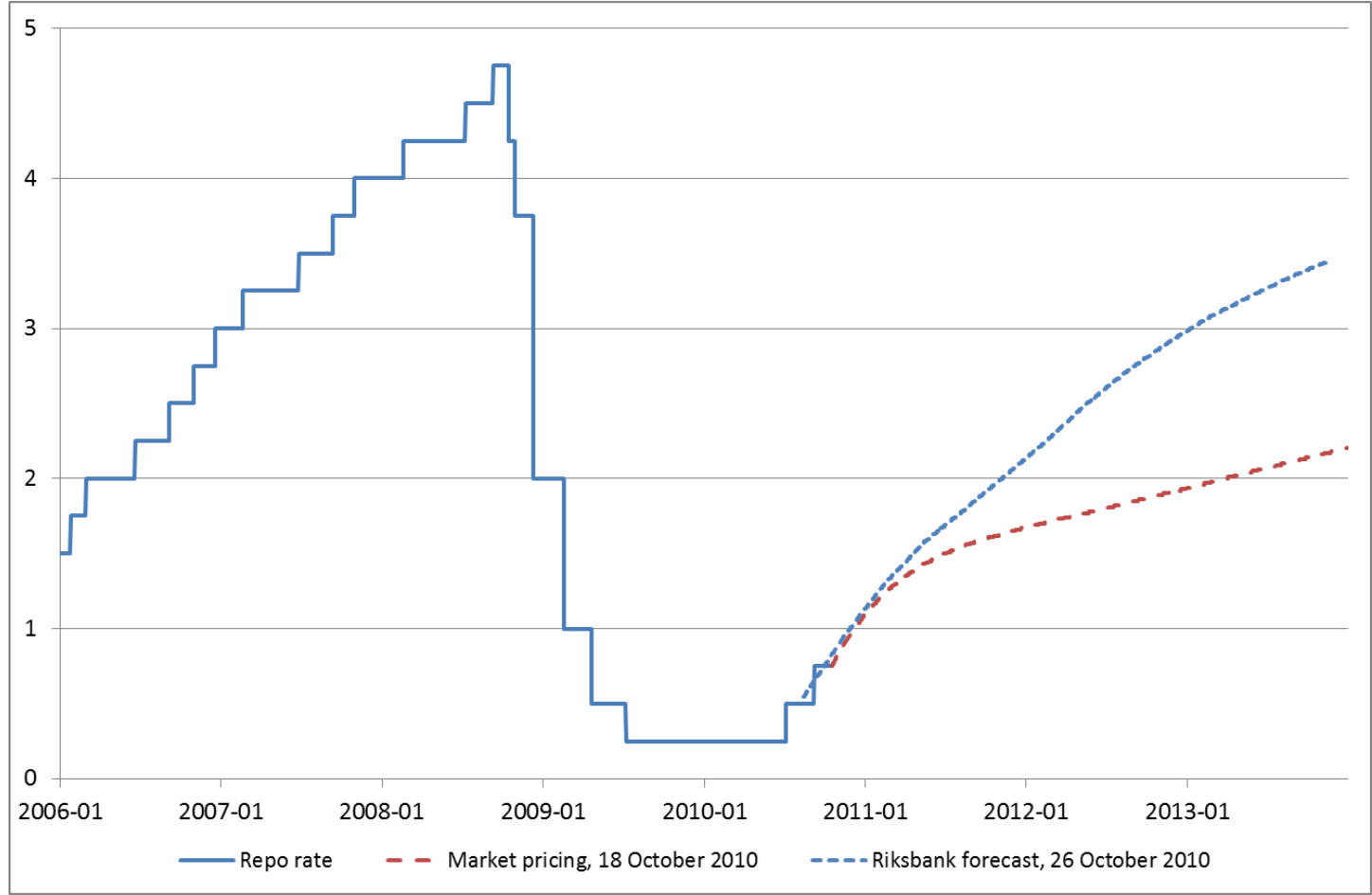

Figure A2. Forecast errors at the one-quarter horizon in Norway.

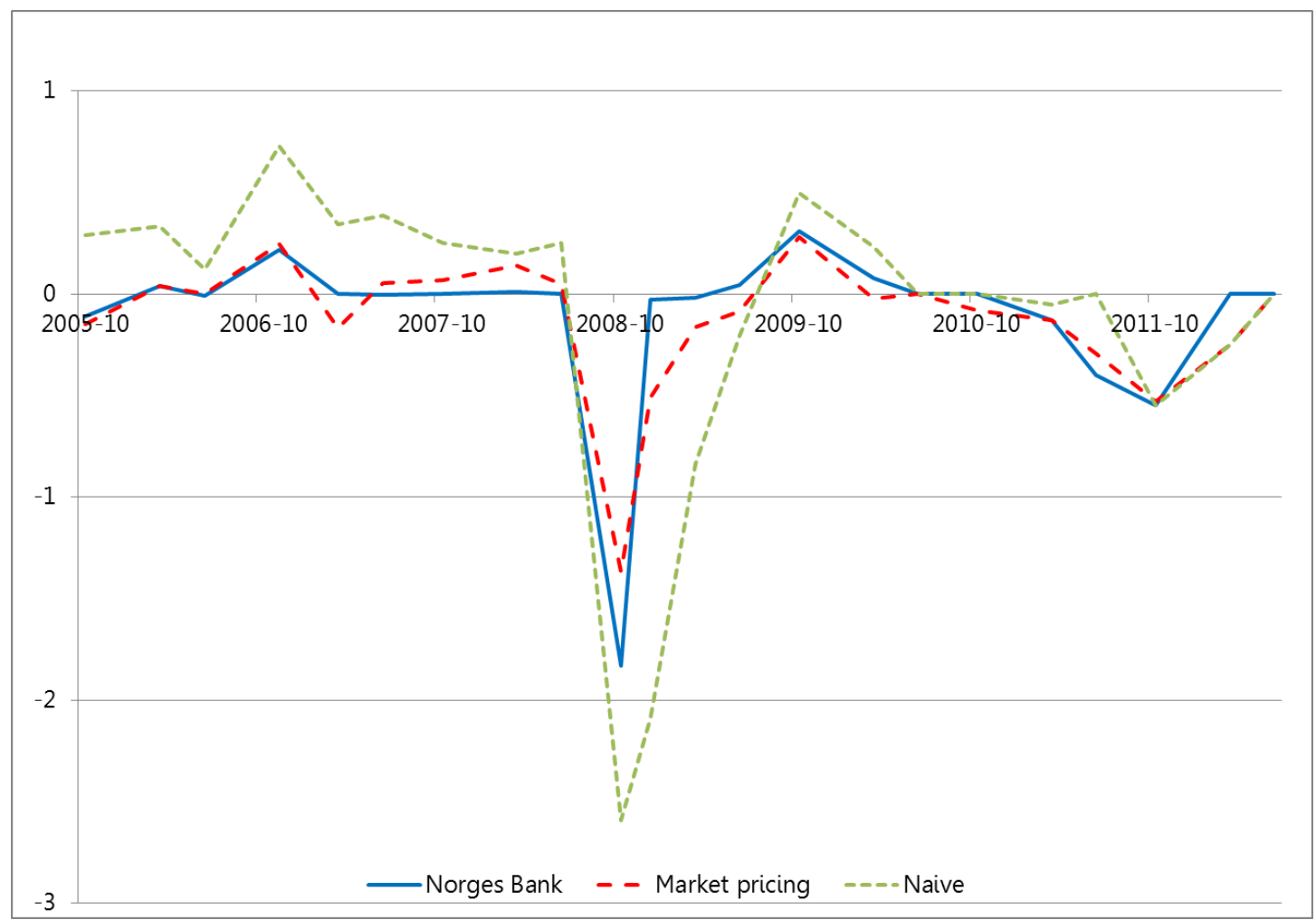

Note: Date refers to when forecast was made. 
Figure A3. Forecast errors at the one-year horizon in Norway.

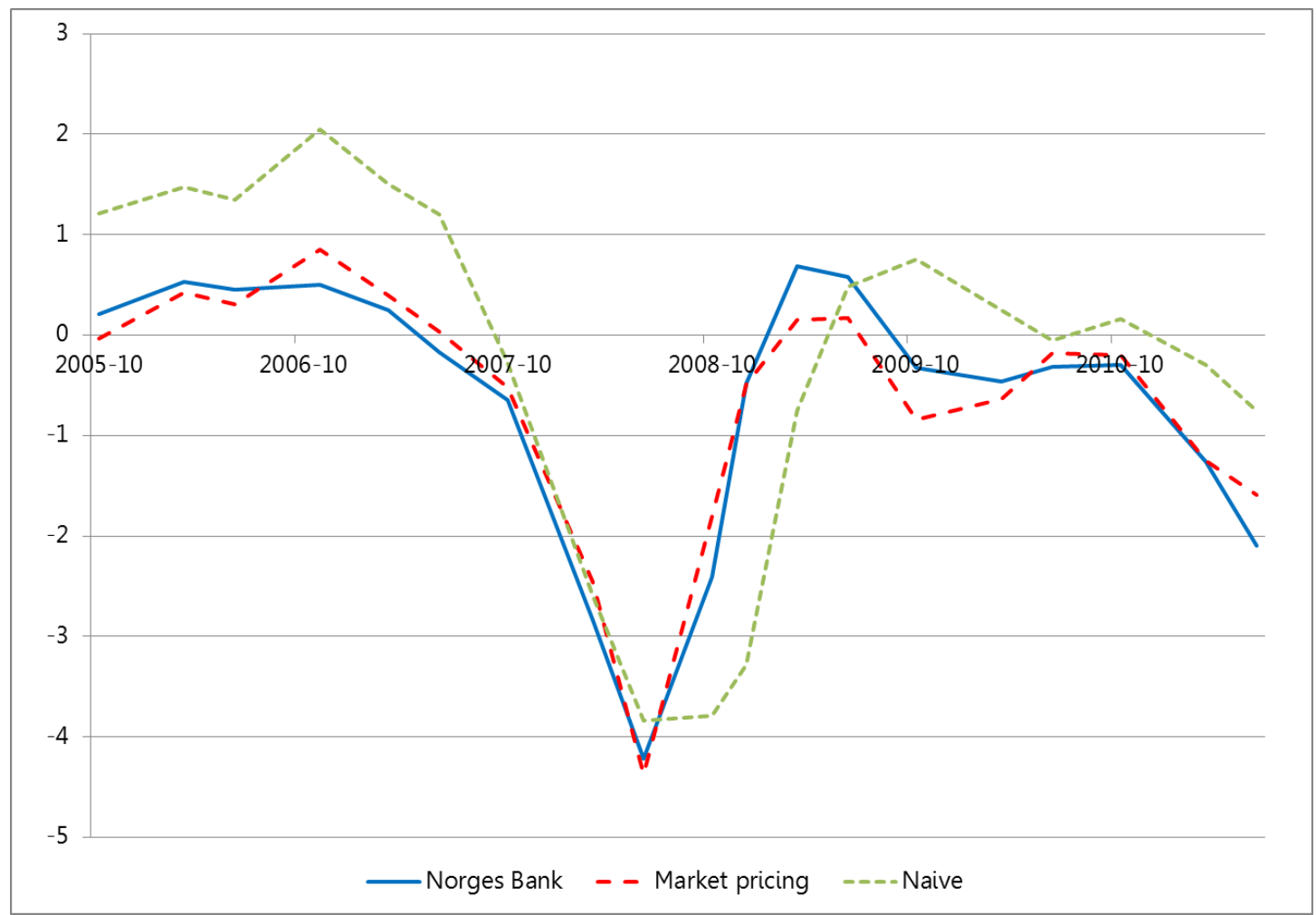

Note: Date refers to when forecast was made.

Figure A4. Forecast errors at the two-year horizon in Norway.

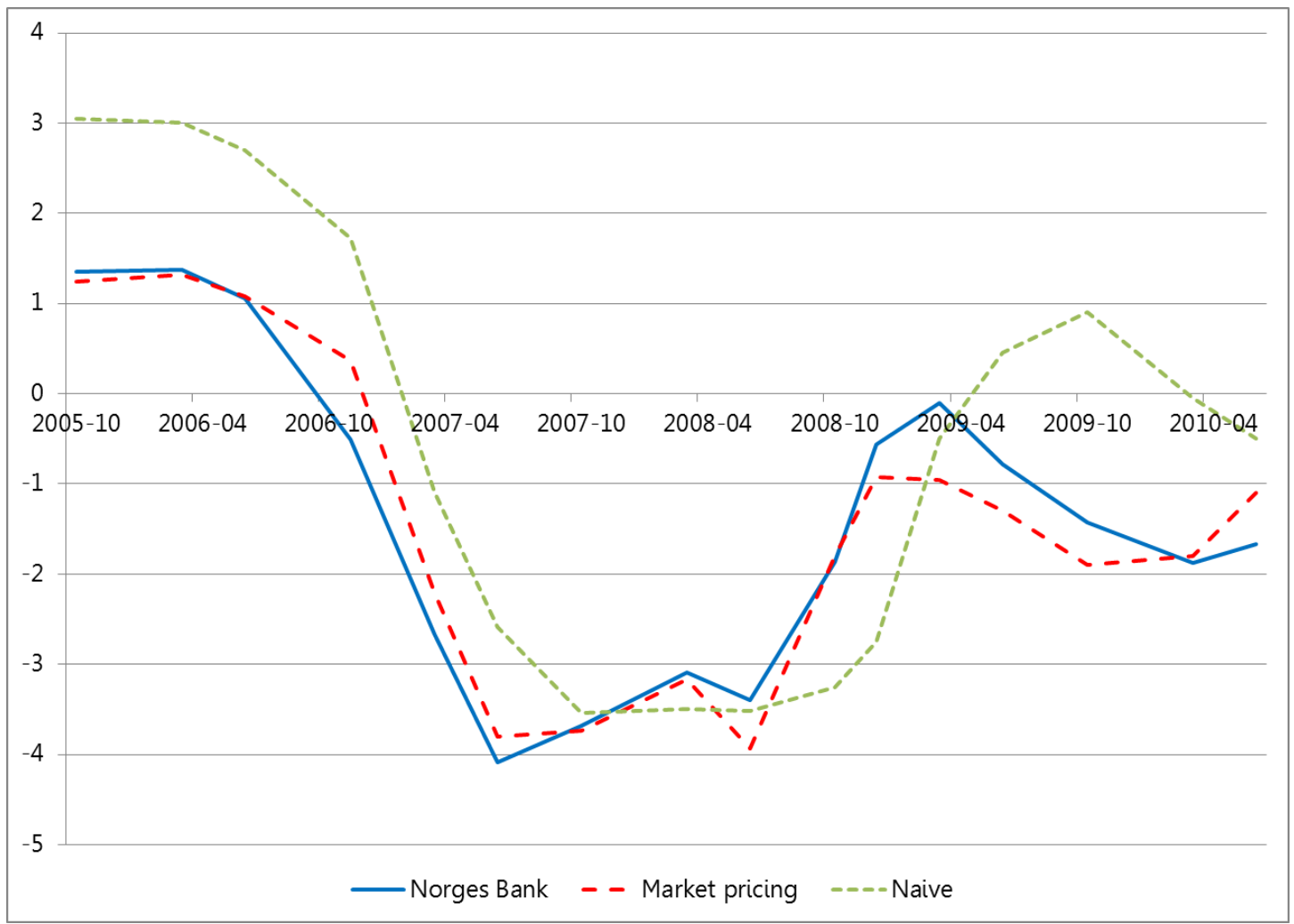

Note: Date refers to when forecast was made. 
Figure A5. Forecast errors at the one-quarter horizon in Sweden.

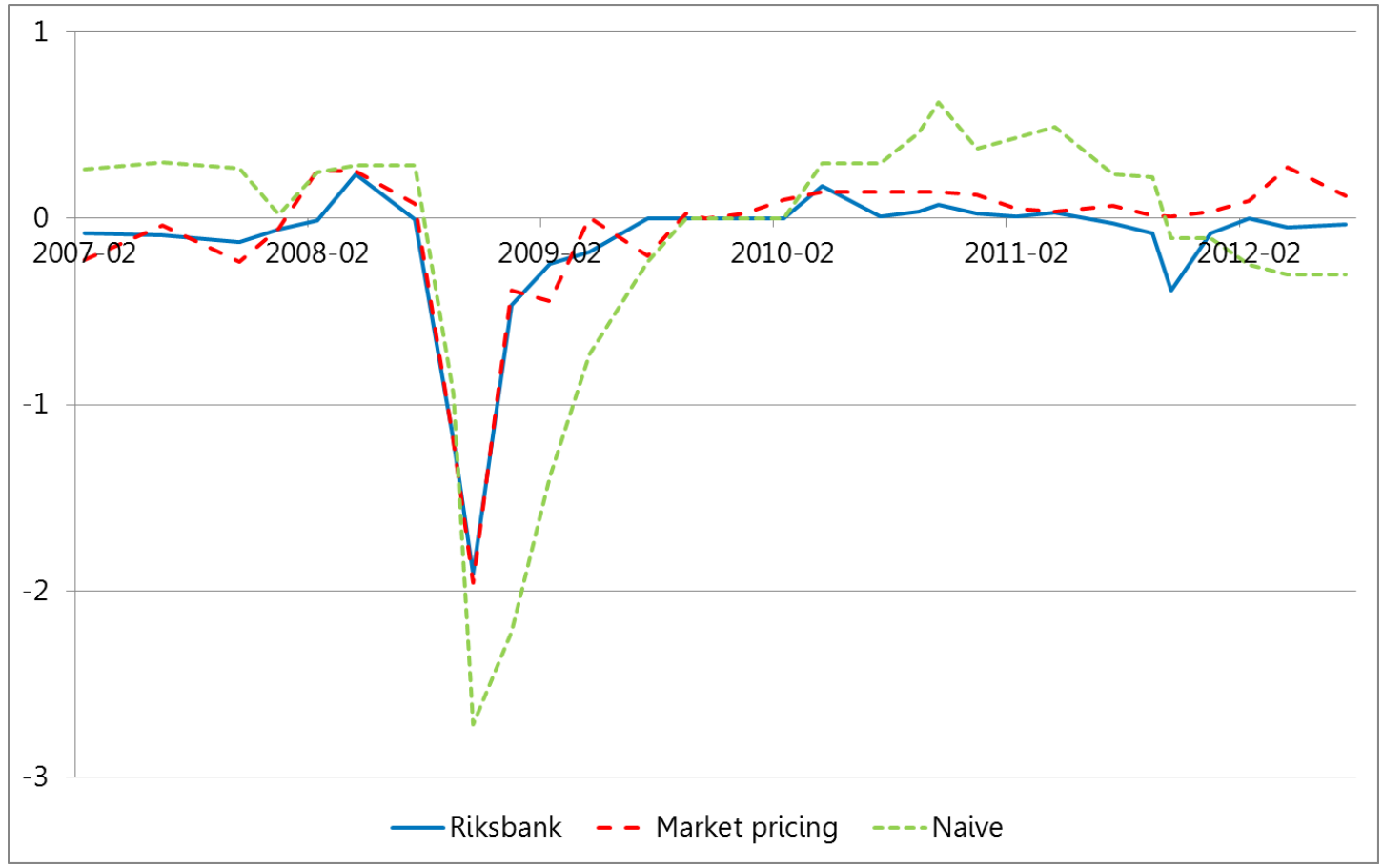

Note: Date refers to when forecast was made.

Figure A6. Forecast errors at the one-year horizon in Sweden.

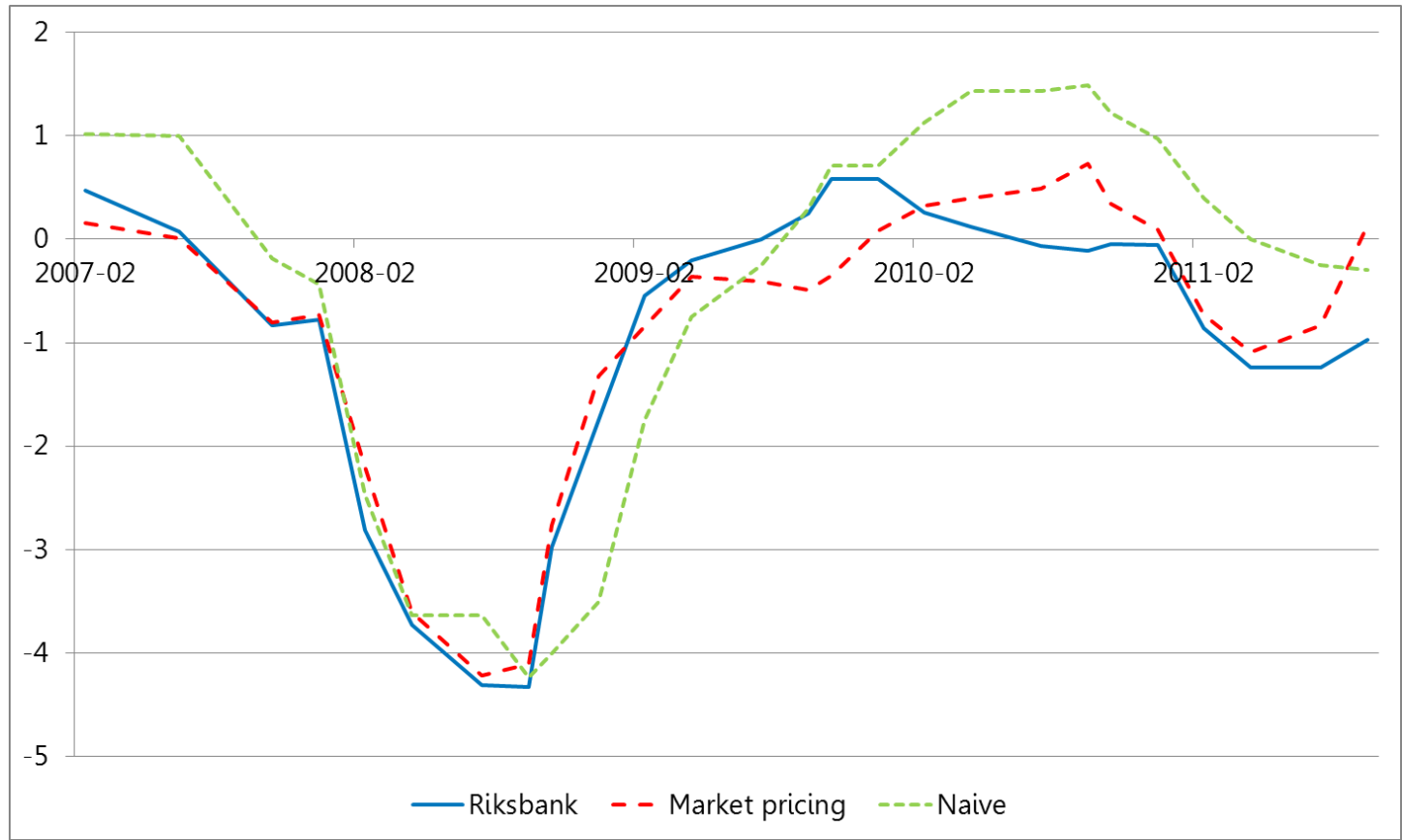

Note: Date refers to when forecast was made. 
Figure A7. Forecast errors at the two-year horizon in Sweden.

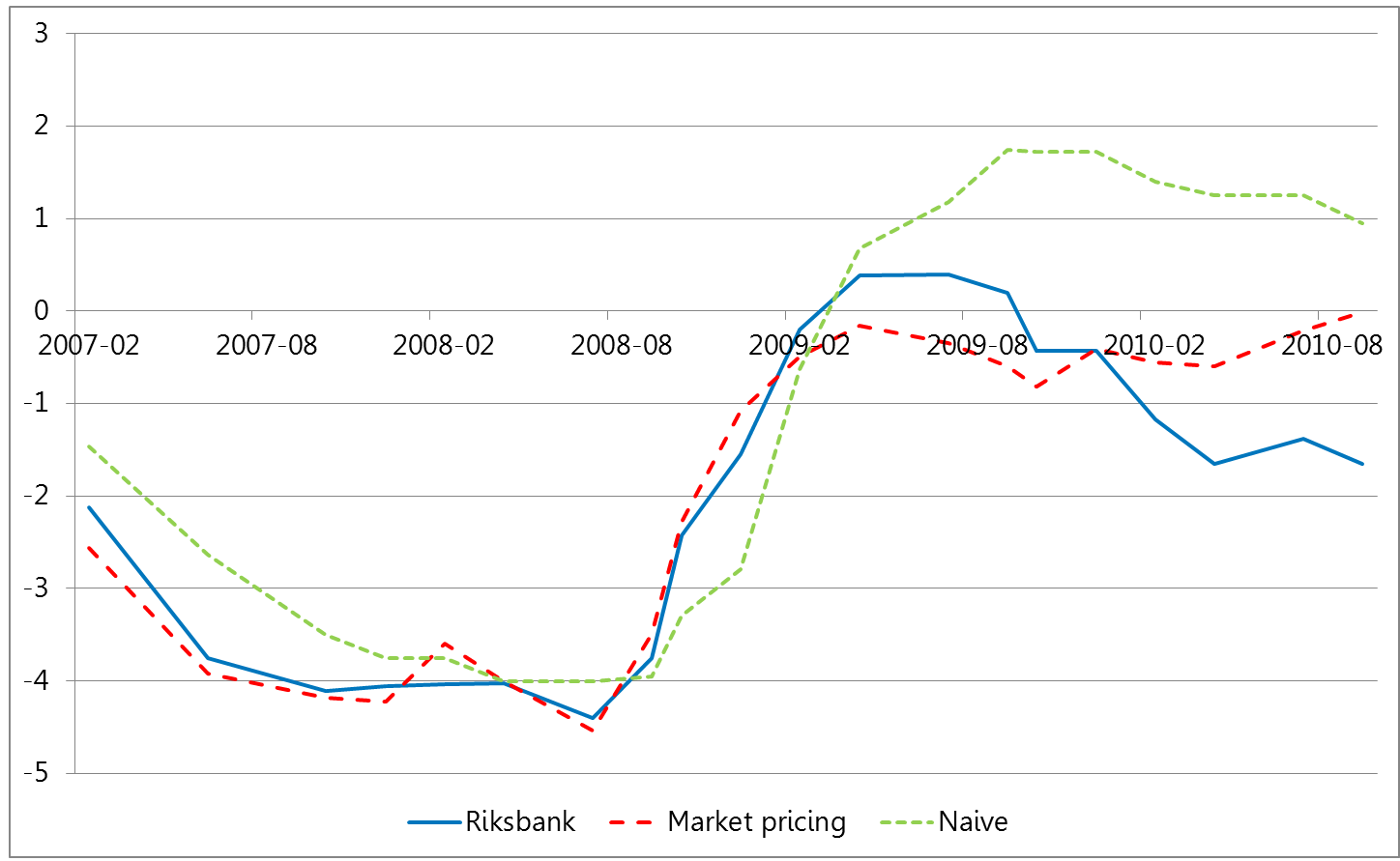

Note: Date refers to when forecast was made. 


\section{Titles in the Working Paper Series}

\begin{tabular}{|c|c|c|c|}
\hline No & Author & Title & Year \\
\hline 1 & $\begin{array}{l}\text { Warne, Anders and } \\
\text { Anders Vredin }\end{array}$ & $\begin{array}{l}\text { Current Account and Business Cycles: Stylized Facts } \\
\text { for Sweden }\end{array}$ & 1989 \\
\hline 2 & Östblom, Göran & $\begin{array}{l}\text { Change in Technical Structure of the Swedish } \\
\text { Economy }\end{array}$ & 1989 \\
\hline 3 & Söderling, Paul & $\begin{array}{l}\text { Mamtax. A Dynamic CGE Model for Tax Reform } \\
\text { Simulations }\end{array}$ & 1989 \\
\hline 4 & $\begin{array}{l}\text { Kanis, Alfred and } \\
\text { Aleksander Markowski }\end{array}$ & $\begin{array}{l}\text { The Supply Side of the Econometric Model of the } \\
\text { NIER }\end{array}$ & 1990 \\
\hline 5 & Berg, Lennart & The Financial Sector in the SNEPQ Model & 1991 \\
\hline 6 & $\begin{array}{l}\text { Ågren, Anders and Bo } \\
\text { Jonsson }\end{array}$ & $\begin{array}{l}\text { Consumer Attitudes, Buying Intentions and } \\
\text { Consumption Expenditures. An Analysis of the } \\
\text { Swedish Household Survey Data }\end{array}$ & 1991 \\
\hline 7 & $\begin{array}{l}\text { Berg, Lennart and } \\
\text { Reinhold Bergström }\end{array}$ & $\begin{array}{l}\text { A Quarterly Consumption Function for Sweden 1979- } \\
1989\end{array}$ & 1991 \\
\hline 8 & Öller, Lars-Erik & $\begin{array}{l}\text { Good Business Cycle Forecasts - A Must for } \\
\text { Stabilization Policies }\end{array}$ & 1992 \\
\hline 9 & $\begin{array}{l}\text { Jonsson, Bo and } \\
\text { Anders Ågren }\end{array}$ & $\begin{array}{l}\text { Forecasting Car Expenditures Using Household } \\
\text { Survey Data }\end{array}$ & 1992 \\
\hline 10 & $\begin{array}{l}\text { Löfgren, Karl-Gustaf, } \\
\text { Bo Ranneby and Sara } \\
\text { Sjöstedt }\end{array}$ & $\begin{array}{l}\text { Forecasting the Business Cycle Not Using Minimum } \\
\text { Autocorrelation Factors }\end{array}$ & 1992 \\
\hline 11 & Gerlach, Stefan & $\begin{array}{l}\text { Current Quarter Forecasts of Swedish GNP Using } \\
\text { Monthly Variables }\end{array}$ & 1992 \\
\hline 12 & Bergström, Reinhold & $\begin{array}{l}\text { The Relationship Between Manufacturing Production } \\
\text { and Different Business Survey Series in Sweden }\end{array}$ & 1992 \\
\hline 13 & $\begin{array}{l}\text { Edlund, Per-Olov and } \\
\text { Sune Karlsson }\end{array}$ & $\begin{array}{l}\text { Forecasting the Swedish Unemployment Rate: VAR } \\
\text { vs. Transfer Function Modelling }\end{array}$ & 1992 \\
\hline 14 & $\begin{array}{l}\text { Rahiala, Markku and } \\
\text { Timo Teräsvirta }\end{array}$ & $\begin{array}{l}\text { Business Survey Data in Forecasting the Output of } \\
\text { Swedish and Finnish Metal and Engineering } \\
\text { Industries: A Kalman Filter Approach }\end{array}$ & 1992 \\
\hline 15 & $\begin{array}{l}\text { Christofferson, } \\
\text { Anders, Roland } \\
\text { Roberts and Ulla } \\
\text { Eriksson }\end{array}$ & $\begin{array}{l}\text { The Relationship Between Manufacturing and Various } \\
\text { BTS Series in Sweden Illuminated by Frequency and } \\
\text { Complex Demodulate Methods }\end{array}$ & 1992 \\
\hline 16 & Jonsson, Bo & $\begin{array}{l}\text { Sample Based Proportions as Values on an } \\
\text { Independent Variable in a Regression Model }\end{array}$ & 1992 \\
\hline 17 & Öller, Lars-Erik & $\begin{array}{l}\text { Eliciting Turning Point Warnings from Business } \\
\text { Surveys }\end{array}$ & 1992 \\
\hline 18 & Forster, Margaret M & $\begin{array}{l}\text { Volatility, Trading Mechanisms and International } \\
\text { Cross-Listing }\end{array}$ & 1992 \\
\hline 19 & Jonsson, Bo & $\begin{array}{l}\text { Prediction with a Linear Regression Model and Errors } \\
\text { in a Regressor }\end{array}$ & 1992 \\
\hline
\end{tabular}




\begin{tabular}{|c|c|c|c|}
\hline 20 & $\begin{array}{l}\text { Gorton, Gary and } \\
\text { Richard Rosen }\end{array}$ & $\begin{array}{l}\text { Corporate Control, Portfolio Choice, and the Decline } \\
\text { of Banking }\end{array}$ & 1993 \\
\hline 21 & $\begin{array}{l}\text { Gustafsson, Claes- } \\
\text { Håkan and Åke } \\
\text { Holmén }\end{array}$ & $\begin{array}{l}\text { The Index of Industrial Production - A Formal } \\
\text { Description of the Process Behind it }\end{array}$ & 1993 \\
\hline 22 & Karlsson, Tohmas & $\begin{array}{l}\text { A General Equilibrium Analysis of the Swedish Tax } \\
\text { Reforms 1989-1991 }\end{array}$ & 1993 \\
\hline 23 & Jonsson, Bo & $\begin{array}{l}\text { Forecasting Car Expenditures Using Household } \\
\text { Survey Data- A Comparison of Different Predictors }\end{array}$ & 1993 \\
\hline 24 & $\begin{array}{l}\text { Gennotte, Gerard and } \\
\text { Hayne Leland }\end{array}$ & Low Margins, Derivative Securitites and Volatility & 1993 \\
\hline 25 & $\begin{array}{l}\text { Boot, Arnoud W.A. } \\
\text { and Stuart I. } \\
\text { Greenbaum }\end{array}$ & Discretion in the Regulation of U.S. Banking & 1993 \\
\hline 26 & $\begin{array}{l}\text { Spiegel, Matthew and } \\
\text { Deane J. Seppi }\end{array}$ & $\begin{array}{l}\text { Does Round-the-Clock Trading Result in Pareto } \\
\text { Improvements? }\end{array}$ & 1993 \\
\hline 27 & Seppi, Deane J. & $\begin{array}{l}\text { How Important are Block Trades in the Price } \\
\text { Discovery Process? }\end{array}$ & 1993 \\
\hline 28 & Glosten, Lawrence R. & Equilibrium in an Electronic Open Limit Order Book & 1993 \\
\hline 29 & $\begin{array}{l}\text { Boot, Arnoud W.A., } \\
\text { Stuart I Greenbaum } \\
\text { and Anjan V. Thakor }\end{array}$ & Reputation and Discretion in Financial Contracting & 1993 \\
\hline $30 \mathrm{a}$ & Bergström, Reinhold & $\begin{array}{l}\text { The Full Tricotomous Scale Compared with Net } \\
\text { Balances in Qualitative Business Survey Data - } \\
\text { Experiences from the Swedish Business Tendency } \\
\text { Surveys }\end{array}$ & 1993 \\
\hline $30 \mathrm{~b}$ & Bergström, Reinhold & $\begin{array}{l}\text { Quantitative Production Series Compared with } \\
\text { Qualiative Business Survey Series for Five Sectors of } \\
\text { the Swedish Manufacturing Industry }\end{array}$ & 1993 \\
\hline 31 & $\begin{array}{l}\text { Lin, Chien-Fu Jeff and } \\
\text { Timo Teräsvirta }\end{array}$ & $\begin{array}{l}\text { Testing the Constancy of Regression Parameters } \\
\text { Against Continous Change }\end{array}$ & 1993 \\
\hline 32 & $\begin{array}{l}\text { Markowski, } \\
\text { Aleksander and } \\
\text { Parameswar } \\
\text { Nandakumar }\end{array}$ & $\begin{array}{l}\text { A Long-Run Equilibrium Model for Sweden. The } \\
\text { Theory Behind the Long-Run Solution to the } \\
\text { Econometric Model KOSMOS }\end{array}$ & 1993 \\
\hline 33 & $\begin{array}{l}\text { Markowski, } \\
\text { Aleksander and Tony } \\
\text { Persson }\end{array}$ & $\begin{array}{l}\text { Capital Rental Cost and the Adjustment for the } \\
\text { Effects of the Investment Fund System in the } \\
\text { Econometric Model Kosmos }\end{array}$ & 1993 \\
\hline 34 & $\begin{array}{l}\text { Kanis, Alfred and } \\
\text { Bharat Barot }\end{array}$ & On Determinants of Private Consumption in Sweden & 1993 \\
\hline 35 & $\begin{array}{l}\text { Kääntä, Pekka and } \\
\text { Christer Tallbom }\end{array}$ & $\begin{array}{l}\text { Using Business Survey Data for Forecasting Swedish } \\
\text { Quantitative Business Cycle Varable. A Kalman Filter } \\
\text { Approach }\end{array}$ & 1993 \\
\hline 36 & $\begin{array}{l}\text { Ohlsson, Henry and } \\
\text { Anders Vredin }\end{array}$ & $\begin{array}{l}\text { Political Cycles and Cyclical Policies. A New Test } \\
\text { Approach Using Fiscal Forecasts }\end{array}$ & 1993 \\
\hline
\end{tabular}




\begin{tabular}{|c|c|c|c|}
\hline 37 & $\begin{array}{l}\text { Markowski, } \\
\text { Aleksander and Lars } \\
\text { Ernsäter }\end{array}$ & $\begin{array}{l}\text { The Supply Side in the Econometric Model } \\
\text { KOSMOS }\end{array}$ & 1994 \\
\hline 38 & $\begin{array}{l}\text { Gustafsson, Claes- } \\
\text { Håkan }\end{array}$ & $\begin{array}{l}\text { On the Consistency of Data on Production, } \\
\text { Deliveries, and Inventories in the Swedish } \\
\text { Manufacturing Industry }\end{array}$ & 1994 \\
\hline 39 & $\begin{array}{l}\text { Rahiala, Markku and } \\
\text { Tapani Kovalainen }\end{array}$ & $\begin{array}{l}\text { Modelling Wages Subject to Both Contracted } \\
\text { Increments and Drift by Means of a Simultaneous- } \\
\text { Equations Model with Non-Standard Error Structure }\end{array}$ & 1994 \\
\hline 40 & $\begin{array}{l}\text { Öller, Lars-Erik and } \\
\text { Christer Tallbom }\end{array}$ & $\begin{array}{l}\text { Hybrid Indicators for the Swedish Economy Based on } \\
\text { Noisy Statistical Data and the Business Tendency } \\
\text { Survey }\end{array}$ & 1994 \\
\hline 41 & Östblom, Göran & $\begin{array}{l}\text { A Converging Triangularization Algorithm and the } \\
\text { Intertemporal Similarity of Production Structures }\end{array}$ & 1994 \\
\hline $42 \mathrm{a}$ & $\begin{array}{l}\text { Markowski, } \\
\text { Aleksander }\end{array}$ & $\begin{array}{l}\text { Labour Supply, Hours Worked and Unemployment in } \\
\text { the Econometric Model KOSMOS }\end{array}$ & 1994 \\
\hline $42 \mathrm{~b}$ & $\begin{array}{l}\text { Markowski, } \\
\text { Aleksander }\end{array}$ & $\begin{array}{l}\text { Wage Rate Determination in the Econometric Model } \\
\text { KOSMOS }\end{array}$ & 1994 \\
\hline 43 & $\begin{array}{l}\text { Ahlroth, Sofia, Anders } \\
\text { Björklund and Anders } \\
\text { Forslund }\end{array}$ & The Output of the Swedish Education Sector & 1994 \\
\hline $44 \mathrm{a}$ & $\begin{array}{l}\text { Markowski, } \\
\text { Aleksander }\end{array}$ & $\begin{array}{l}\text { Private Consumption Expenditure in the Econometric } \\
\text { Model KOSMOS }\end{array}$ & 1994 \\
\hline $44 \mathrm{~b}$ & $\begin{array}{l}\text { Markowski, } \\
\text { Aleksander }\end{array}$ & $\begin{array}{l}\text { The Input-Output Core: Determination of Inventory } \\
\text { Investment and Other Business Output in the } \\
\text { Econometric Model KOSMOS }\end{array}$ & 1994 \\
\hline 45 & Bergström, Reinhold & $\begin{array}{l}\text { The Accuracy of the Swedish National Budget } \\
\text { Forecasts 1955-92 }\end{array}$ & 1995 \\
\hline 46 & Sjöö, Boo & $\begin{array}{l}\text { Dynamic Adjustment and Long-Run Economic } \\
\text { Stability }\end{array}$ & 1995 \\
\hline $47 \mathrm{a}$ & $\begin{array}{l}\text { Markowski, } \\
\text { Aleksander }\end{array}$ & $\begin{array}{l}\text { Determination of the Effective Exchange Rate in the } \\
\text { Econometric Model KOSMOS }\end{array}$ & 1995 \\
\hline $47 \mathrm{~b}$ & $\begin{array}{l}\text { Markowski, } \\
\text { Aleksander }\end{array}$ & $\begin{array}{l}\text { Interest Rate Determination in the Econometric } \\
\text { Model KOSMOS }\end{array}$ & 1995 \\
\hline 48 & Barot, Bharat & $\begin{array}{l}\text { Estimating the Effects of Wealth, Interest Rates and } \\
\text { Unemployment on Private Consumption in Sweden }\end{array}$ & 1995 \\
\hline 49 & Lundvik, Petter & Generational Accounting in a Small Open Economy & 1996 \\
\hline 50 & $\begin{array}{l}\text { Eriksson, Kimmo, } \\
\text { Johan Karlander and } \\
\text { Lars-Erik Öller }\end{array}$ & Hierarchical Assignments: Stability and Fairness & 1996 \\
\hline 51 & Url, Thomas & Internationalists, Regionalists, or Eurocentrists & 1996 \\
\hline 52 & Ruist, Erik & Temporal Aggregation of an Econometric Equation & 1996 \\
\hline 53 & $\begin{array}{l}\text { Markowski, } \\
\text { Aleksander }\end{array}$ & $\begin{array}{l}\text { The Financial Block in the Econometric Model } \\
\text { KOSMOS }\end{array}$ & 1996 \\
\hline
\end{tabular}




\begin{tabular}{|c|c|c|c|}
\hline 54 & Östblom, Göran & $\begin{array}{l}\text { Emissions to the Air and the Allocation of GDP: } \\
\text { Medium Term Projections for Sweden. In Conflict } \\
\text { with the Goals of } \mathrm{SO}_{2}, \mathrm{SO}_{2} \text { and NOX Emissions for } \\
\text { Year } 2000\end{array}$ & 1996 \\
\hline 55 & $\begin{array}{l}\text { Koskinen, Lasse, } \\
\text { Aleksander } \\
\text { Markowski, } \\
\text { Parameswar } \\
\text { Nandakumar and } \\
\text { Lars-Erik Öller } \\
\end{array}$ & Three Seminar Papers on Output Gap & 1997 \\
\hline 56 & $\begin{array}{l}\text { Oke, Timothy and } \\
\text { Lars-Erik Öller }\end{array}$ & Testing for Short Memory in a VARMA Process & 1997 \\
\hline 57 & $\begin{array}{l}\text { Johansson, Anders } \\
\text { and Karl-Markus } \\
\text { Modén }\end{array}$ & Investment Plan Revisions and Share Price Volatility & 1997 \\
\hline 58 & Lyhagen, Johan & $\begin{array}{l}\text { The Effect of Precautionary Saving on Consumption } \\
\text { in Sweden }\end{array}$ & 1998 \\
\hline 59 & $\begin{array}{l}\text { Koskinen, Lasse and } \\
\text { Lars-Erik Öller }\end{array}$ & $\begin{array}{l}\text { A Hidden Markov Model as a Dynamic Bayesian } \\
\text { Classifier, with an Application to Forecasting } \\
\text { Business-Cycle Turning Points }\end{array}$ & 1998 \\
\hline 60 & $\begin{array}{l}\text { Kragh, Börje and } \\
\text { Aleksander Markowski }\end{array}$ & $\begin{array}{l}\text { Kofi - a Macromodel of the Swedish Financial } \\
\text { Markets }\end{array}$ & 1998 \\
\hline 61 & $\begin{array}{l}\text { Gajda, Jan B. and } \\
\text { Aleksander Markowski }\end{array}$ & $\begin{array}{l}\text { Model Evaluation Using Stochastic Simulations: The } \\
\text { Case of the Econometric Model KOSMOS }\end{array}$ & 1998 \\
\hline 62 & Johansson, Kerstin & Exports in the Econometric Model KOSMOS & 1998 \\
\hline 63 & Johansson, Kerstin & $\begin{array}{l}\text { Permanent Shocks and Spillovers: A Sectoral } \\
\text { Approach Using a Structural VAR }\end{array}$ & 1998 \\
\hline 64 & $\begin{array}{l}\text { Öller, Lars-Erik and } \\
\text { Bharat Barot }\end{array}$ & Comparing the Accuracy of European GDP Forecasts & 1999 \\
\hline 65 & $\begin{array}{l}\text { Huhtala, Anni and } \\
\text { Eva Samakovlis }\end{array}$ & $\begin{array}{l}\text { Does International Harmonization of Environmental } \\
\text { Policy Instruments Make Economic Sense? The Case } \\
\text { of Paper Recycling in Europe }\end{array}$ & 1999 \\
\hline 66 & Nilsson, Charlotte & $\begin{array}{l}\text { A Unilateral Versus a Multilateral Carbon Dioxide } \\
\text { Tax - A Numerical Analysis With The European } \\
\text { Model GEM-E3 }\end{array}$ & 1999 \\
\hline 67 & $\begin{array}{l}\text { Braconier, Henrik and } \\
\text { Steinar Holden }\end{array}$ & $\begin{array}{l}\text { The Public Budget Balance - Fiscal Indicators and } \\
\text { Cyclical Sensitivity in the Nordic Countries }\end{array}$ & 1999 \\
\hline 68 & Nilsson, Kristian & $\begin{array}{l}\text { Alternative Measures of the Swedish Real Exchange } \\
\text { Rate }\end{array}$ & 1999 \\
\hline 69 & Östblom, Göran & $\begin{array}{l}\text { An Environmental Medium Term Economic Model - } \\
\text { EMEC }\end{array}$ & 1999 \\
\hline 70 & $\begin{array}{l}\text { Johnsson, Helena and } \\
\text { Peter Kaplan }\end{array}$ & $\begin{array}{l}\text { An Econometric Study of Private Consumption } \\
\text { Expenditure in Sweden }\end{array}$ & 1999 \\
\hline 71 & $\begin{array}{l}\text { Arai, Mahmood and } \\
\text { Fredrik Heyman }\end{array}$ & $\begin{array}{l}\text { Permanent and Temporary Labour: Job and Worker } \\
\text { Flows in Sweden 1989-1998 }\end{array}$ & 2000 \\
\hline
\end{tabular}




\begin{tabular}{|c|c|c|c|}
\hline 72 & $\begin{array}{l}\text { Öller, Lars-Erik and } \\
\text { Bharat Barot }\end{array}$ & $\begin{array}{l}\text { The Accuracy of European Growth and Inflation } \\
\text { Forecasts }\end{array}$ & 2000 \\
\hline 73 & Ahlroth, Sofia & $\begin{array}{l}\text { Correcting Net Domestic Product for Sulphur } \\
\text { Dioxide and Nitrogen Oxide Emissions: } \\
\text { Implementation of a Theoretical Model in Practice }\end{array}$ & 2000 \\
\hline 74 & $\begin{array}{l}\text { Andersson, Michael } \\
\text { K. And Mikael P. } \\
\text { Gredenhoff }\end{array}$ & $\begin{array}{l}\text { Improving Fractional Integration Tests with } \\
\text { Bootstrap Distribution }\end{array}$ & 2000 \\
\hline 75 & $\begin{array}{l}\text { Nilsson, Charlotte and } \\
\text { Anni Huhtala }\end{array}$ & $\begin{array}{l}\text { Is } \mathrm{CO}_{2} \text { Trading Always Beneficial? A CGE-Model } \\
\text { Analysis on Secondary Environmental Benefits }\end{array}$ & 2000 \\
\hline 76 & Skånberg, Kristian & $\begin{array}{l}\text { Constructing a Partially Environmentally Adjusted } \\
\text { Net Domestic Product for Sweden } 1993 \text { and } 1997\end{array}$ & 2001 \\
\hline 77 & $\begin{array}{l}\text { Huhtala, Anni, Annie } \\
\text { Toppinen and Mattias } \\
\text { Boman, }\end{array}$ & $\begin{array}{l}\text { An Environmental Accountant's Dilemma: Are } \\
\text { Stumpage Prices Reliable Indicators of Resource } \\
\text { Scarcity? }\end{array}$ & 2001 \\
\hline 78 & Nilsson, Kristian & $\begin{array}{l}\text { Do Fundamentals Explain the Behavior of the Real } \\
\text { Effective Exchange Rate? }\end{array}$ & 2002 \\
\hline 79 & Bharat, Barot & $\begin{array}{l}\text { Growth and Business Cycles for the Swedish } \\
\text { Economy }\end{array}$ & 2002 \\
\hline 80 & Bharat, Barot & $\begin{array}{l}\text { House Prices and Housing Investment in Sweden and } \\
\text { the United Kingdom. Econometric Analysis for the } \\
\text { Period 1970-1998 }\end{array}$ & 2002 \\
\hline 81 & Hjelm, Göran & $\begin{array}{l}\text { Simultaneous Determination of NAIRU, Output } \\
\text { Gaps and Structural Budget Balances: Swedish } \\
\text { Evidence }\end{array}$ & 2003 \\
\hline 82 & $\begin{array}{l}\text { Huhtala, Anni and } \\
\text { Eva Samalkovis }\end{array}$ & Green Accounting, Air Pollution and Health & 2003 \\
\hline 83 & Lindström, Tomas & $\begin{array}{l}\text { The Role of High-Tech Capital Formation for } \\
\text { Swedish Productivity Growth }\end{array}$ & 2003 \\
\hline 84 & $\begin{array}{l}\text { Hansson, Jesper, Per } \\
\text { Jansson and Mårten } \\
\text { Löf }\end{array}$ & $\begin{array}{l}\text { Business survey data: do they help in forecasting the } \\
\text { macro economy? }\end{array}$ & 2003 \\
\hline 85 & $\begin{array}{l}\text { Boman, Mattias, Anni } \\
\text { Huhtala, Charlotte } \\
\text { Nilsson, Sofia } \\
\text { Ahlroth, Göran } \\
\text { Bostedt, Leif Mattson } \\
\text { and Peichen Gong }\end{array}$ & $\begin{array}{l}\text { Applying the Contingent Valuation Method in } \\
\text { Resource Accounting: A Bold Proposal }\end{array}$ & \\
\hline 86 & Gren, Ing-Marie & Monetary Green Accounting and Ecosystem Services & 2003 \\
\hline 87 & $\begin{array}{l}\text { Samakovlis, Eva, Anni } \\
\text { Huhtala, Tom } \\
\text { Bellander and Magnus } \\
\text { Svartengren }\end{array}$ & $\begin{array}{l}\text { Air Quality and Morbidity: Concentration-response } \\
\text { Relationships for Sweden }\end{array}$ & 2004 \\
\hline 88 & $\begin{array}{l}\text { Alsterlind, Jan, Alek } \\
\text { Markowski and } \\
\text { Kristian Nilsson } \\
\end{array}$ & $\begin{array}{l}\text { Modelling the Foreign Sector in a Macroeconometric } \\
\text { Model of Sweden }\end{array}$ & 2004 \\
\hline 89 & Lindén, Johan & The Labor Market in KIMOD & 2004 \\
\hline
\end{tabular}




\begin{tabular}{|c|c|c|c|}
\hline 90 & $\begin{array}{l}\text { Henrik Braconier, } \\
\text { Tomas Forsfält }\end{array}$ & $\begin{array}{l}\text { A New Method for Constructing a Cyclically Adjusted } \\
\text { Budget Balance: the Case of Sweden }\end{array}$ & 2004 \\
\hline 91 & $\begin{array}{l}\text { Hansen, Sten and } \\
\text { Tomas Lindström }\end{array}$ & Is Rising Returns to Scale a Figment of Poor Data? & 2004 \\
\hline 92 & Hjelm, Göran & $\begin{array}{l}\text { When Are Fiscal Contractions Successful? Lessons for } \\
\text { Countries Within and Outside the EMU }\end{array}$ & 2004 \\
\hline 93 & $\begin{array}{l}\text { Östblom, Göran and } \\
\text { Samakovlis, Eva }\end{array}$ & $\begin{array}{l}\text { Costs of Climate Policy when Pollution Affects } \\
\text { Health and Labour Productivity. A General } \\
\text { Equilibrium Analysis Applied to Sweden }\end{array}$ & 2004 \\
\hline 94 & $\begin{array}{l}\text { Forslund Johanna, } \\
\text { Eva Samakovlis and } \\
\text { Maria Vredin } \\
\text { Johansson }\end{array}$ & $\begin{array}{l}\text { Matters Risk? The Allocation of Government } \\
\text { Subsidies for Remediation of Contaminated Sites } \\
\text { under the Local Investment Programme }\end{array}$ & 2006 \\
\hline 95 & $\begin{array}{l}\text { Erlandsson Mattias } \\
\text { and Alek Markowski }\end{array}$ & $\begin{array}{l}\text { The Effective Exchange Rate Index KIX - Theory } \\
\text { and Practice }\end{array}$ & 2006 \\
\hline 96 & $\begin{array}{l}\text { Östblom Göran and } \\
\text { Charlotte Berg }\end{array}$ & The EMEC model: Version 2.0 & 2006 \\
\hline 97 & $\begin{array}{l}\text { Hammar, Henrik, } \\
\text { Tommy Lundgren and } \\
\text { Magnus Sjöström }\end{array}$ & $\begin{array}{l}\text { The significance of transport costs in the Swedish } \\
\text { forest industry }\end{array}$ & 2006 \\
\hline 98 & Barot, Bharat & $\begin{array}{l}\text { Empirical Studies in Consumption, House Prices and } \\
\text { the Accuracy of European Growth and Inflation } \\
\text { Forecasts }\end{array}$ & 2006 \\
\hline 99 & Hjelm, Göran & $\begin{array}{l}\text { Kan arbetsmarknadens parter minska } \\
\text { jämviktsarbetslösheten? Teori och modellsimuleringar }\end{array}$ & 2006 \\
\hline 100 & $\begin{array}{l}\text { Bergvall, Anders, } \\
\text { Tomas Forsfält, } \\
\text { Göran Hjelm, } \\
\text { Jonny Nilsson and } \\
\text { Juhana Vartiainen }\end{array}$ & $\begin{array}{l}\text { KIMOD 1.0 Documentation of NIER's Dynamic } \\
\text { Macroeconomic General Equilibrium Model of the } \\
\text { Swedish Economy }\end{array}$ & 2007 \\
\hline 101 & Östblom, Göran & $\begin{array}{l}\text { Nitrogen and Sulphur Outcomes of a Carbon } \\
\text { Emissions Target Excluding Traded Allowances - } \\
\text { An Input-Output Analysis of the Swedish Case }\end{array}$ & 2007 \\
\hline 102 & $\begin{array}{l}\text { Hammar, Henrik and } \\
\text { Åsa Löfgren }\end{array}$ & $\begin{array}{l}\text { Explaining adoption of end of pipe solutions and } \\
\text { clean technologies - Determinants of firms' } \\
\text { investments for reducing emissions to air in four } \\
\text { sextors in Sweden }\end{array}$ & 2007 \\
\hline 103 & $\begin{array}{l}\text { Östblom, Göran and } \\
\text { Henrik Hammar }\end{array}$ & $\begin{array}{l}\text { Outcomes of a Swedish Kilometre Tax. An Analysis } \\
\text { of Economic Effects and Effects on NOx Emissions }\end{array}$ & 2007 \\
\hline 104 & $\begin{array}{l}\text { Forsfält, Tomas, } \\
\text { Johnny Nilsson and } \\
\text { Juhana Vartianinen }\end{array}$ & $\begin{array}{l}\text { Modellansatser i Konjunkturinstitutets } \\
\text { medelfristprognoser }\end{array}$ & 208 \\
\hline 105 & Samakovlis, Eva & $\begin{array}{l}\text { How are Green National Accounts Produced in } \\
\text { Practice? }\end{array}$ & 2008 \\
\hline
\end{tabular}




\begin{tabular}{|c|c|c|c|}
\hline 107 & $\begin{array}{l}\text { Forslund, Johanna, } \\
\text { Per Johansson, Eva } \\
\text { Samakovlis and Maria } \\
\text { Vredin Johansson }\end{array}$ & $\begin{array}{l}\text { Can we by time? Evaluation. Evaluation of the } \\
\text { government's directed grant to remediation in Sweden }\end{array}$ & 2009 \\
\hline 108 & $\begin{array}{l}\text { Forslund, Johanna } \\
\text { Eva Samakovlis, Maria } \\
\text { Vredin Johansson and } \\
\text { Lars Barregård }\end{array}$ & $\begin{array}{l}\text { Does Remediation Save Lives? } \\
\text { On the Cost of Cleaning Up } \\
\text { Arsenic-Contaminated } \\
\text { Sites in Sweden }\end{array}$ & 2009 \\
\hline 109 & $\begin{array}{l}\text { Sjöström, Magnus and } \\
\text { Göran Östblom }\end{array}$ & $\begin{array}{l}\text { Future Waste Scenarios for Sweden on the Basis of a } \\
\text { CGE-model }\end{array}$ & 2009 \\
\hline 110 & Österholm, Pär & $\begin{array}{l}\text { The Effect on the Swedish Real Economy of the } \\
\text { Financial Crisis }\end{array}$ & 2009 \\
\hline 111 & Forsfält, Tomas & $\begin{array}{l}\text { KIMOD } 2.0 \text { Documentation of changes in the model } \\
\text { from January } 2007 \text { to January } 2009\end{array}$ & 2009 \\
\hline 112 & Österholm, Pär & $\begin{array}{l}\text { Improving Unemployment Rate Forecasts Using } \\
\text { Survey Data }\end{array}$ & 2009 \\
\hline 113 & Österholm, Pär & $\begin{array}{l}\text { Unemployment and Labour-Force } \\
\text { Participation in Sweden }\end{array}$ & 2009 \\
\hline 114 & $\begin{array}{l}\text { Jonsson, Thomas and } \\
\text { Pär Österholm }\end{array}$ & $\begin{array}{l}\text { The Properties of Survey-Based } \\
\text { Inflation Expectations in Sweden }\end{array}$ & 2009 \\
\hline 115 & $\begin{array}{l}\text { Hjelm, Göran and } \\
\text { Kristian Jönsson }\end{array}$ & $\begin{array}{l}\text { In Search of a Method for Measuring the Output Gap } \\
\text { of the Swedish Economy }\end{array}$ & 2010 \\
\hline 116 & Vartiainen, Juhana & Interpreting Wage Bargaining Norms & 2010 \\
\hline 117 & $\begin{array}{l}\text { Mossfeldt, Marcus and } \\
\text { Pär Österholm }\end{array}$ & $\begin{array}{l}\text { The Persistent Labour-Market Effects of the Financial } \\
\text { Crisis }\end{array}$ & 2010 \\
\hline 118 & $\begin{array}{l}\text { Östblom, Göran, } \\
\text { Maria Ljunggren } \\
\text { Söderman and Magnus } \\
\text { Sjöström }\end{array}$ & $\begin{array}{l}\text { Analysing future solid waste generation - Soft linking } \\
\text { a model of waste management with a CGE-model for } \\
\text { Sweden }\end{array}$ & 2010 \\
\hline 119 & $\begin{array}{l}\text { Broberg, Thomas, } \\
\text { Per-Olov Marklund, } \\
\text { Eva Samakovlisa and } \\
\text { Henrik Hammar }\end{array}$ & $\begin{array}{l}\text { Does environmental leadership pay off for Swed-ish } \\
\text { industry? - Analyzing the effects of environ-mental } \\
\text { investments on efficiency }\end{array}$ & 2010 \\
\hline 120 & $\begin{array}{l}\text { Gustavsson, Magnus } \\
\text { and Pär Österholm }\end{array}$ & $\begin{array}{l}\text { Labor-Force Participation Rates and the } \\
\text { Informational Value of Unemployment Rates: } \\
\text { Evidence from Disaggregated US Data }\end{array}$ & 2010 \\
\hline 121 & $\begin{array}{l}\text { Jonsson, Thomas and } \\
\text { Pär österholm }\end{array}$ & $\begin{array}{l}\text { The Forecasting Properties of Survey-Based Wage- } \\
\text { Growth Expectations }\end{array}$ & 2010 \\
\hline 122 & $\begin{array}{l}\text { Antipin, Jan-Erik, } \\
\text { Jimmy Boumediene } \\
\text { and Pär Österholm }\end{array}$ & $\begin{array}{l}\text { On the Usefulness of Constant Gain Least Squares } \\
\text { when Forecasting the Unemployment Rate }\end{array}$ & 2011 \\
\hline 123 & $\begin{array}{l}\text { Broberg, Thomas, } \\
\text { Tomas Forsfält and } \\
\text { Göran Östblom }\end{array}$ & $\begin{array}{l}\text { The Excess Cost of Supplementary Constraints in } \\
\text { Climate Policy: The Case of Sweden's Energy } \\
\text { Intensity Target }\end{array}$ & 2011 \\
\hline
\end{tabular}




\begin{tabular}{|c|c|c|c|}
\hline 124 & $\begin{array}{l}\text { Patrik Baard, Henrik } \\
\text { Carlsen, Karin } \\
\text { Edvardsson Björnberg } \\
\text { and Maria Vredin } \\
\text { Johansson }\end{array}$ & $\begin{array}{l}\text { Scenarios and Sustainability. A Swedish Case Study of } \\
\text { Adaptation Tools for Local Decision-Makers }\end{array}$ & 2011 \\
\hline 125 & $\begin{array}{l}\text { Hansson, Sven Ove, } \\
\text { Karin Edvardsson } \\
\text { Björnberg and } \\
\text { Maria Vredin } \\
\text { Johansson }\end{array}$ & $\begin{array}{l}\text { Making Climate Policy Efficient } \\
\text { Implementing a Model for Environmental Policy } \\
\text { Efficiency }\end{array}$ & 2011 \\
\hline 126 & $\begin{array}{l}\text { Antipin, Jan-Erik, } \\
\text { Farid Jimmy } \\
\text { Boumediene and Pär } \\
\text { Österholm }\end{array}$ & $\begin{array}{l}\text { Forecasting Inflation Using Constant Gain Least } \\
\text { Squares }\end{array}$ & 2012 \\
\hline 127 & $\begin{array}{l}\text { Meredith Beechey, Pär } \\
\text { Österholm }\end{array}$ & $\begin{array}{l}\text { Policy Interest Rate Expectations in Sweden: A } \\
\text { Forecast Evaluation }\end{array}$ & 2012 \\
\hline 128 & $\begin{array}{l}\text { Meredith Beechey, Pär } \\
\text { Österholm }\end{array}$ & $\begin{array}{l}\text { Central Bank Forecasts of Policy Interest Rates: An } \\
\text { Evaluation of the First Years }\end{array}$ & 2013 \\
\hline
\end{tabular}


Konjunkturinstitutet, Kungsgatan 12-14, Box 3116, 10362 Stockholm

Tel: 08-453 59 00, Fax: 08-453 59 80, E-post: ki@konj.se, Webb: konj.se 